\title{
PENSION REFORM IN THE CZECH REPUBLIC: PRESENT SITUATION AND FUTURE PROSPECTS (a comparison with Austria)
}

\author{
Marie VAVREJNOVÁ*, Eva BELABED**, Karl WÖRISTER***
}

\begin{abstract}
:
This paper deals with present situation and future development of pension reform in the Czech Republic. A comparison with neighboring country - Austria, has been done. Parametrical reforms of pay as you go systems in both countries are compared and evaluated. Pretensions to introduce the multi-pillar pension system are commented and appraised. Some opacities in current definitions of private pension systems are mentioned. Specific risks of different pillars are introduced, together with the necessity to monitor costs of the pension administrative itself. Aging of the society and public budgets deficit are very important circumstances influencing the pension policy, however, the main aim of reforms should be the creation of a modern system, supporting the maintenance of the living standard of the elderly. Well functioning labour market and developed financial market for a modern pension system are indispensable.
\end{abstract}

Keywords: pension reforms, aging, multi-pillar system, labour market

JEL Classification: J14, J18, J21, J26

\section{Introduction}

Pensions are at present the main item of public social expenditures, nearly one half of them in countries where the public pay as you go (PAYG) pension system has been applied. In the course of last years the deficit of the balance of social contributions and social expenditures precariously accumulated and conduced to the overall deficit of the public finances. Therefore, in most European countries further sources are looked for to cover it. A world-wide discussion has developed about the improvement of pension systems. The Czech Republic has been also participating in this process, strengthened by the struggle with numberless problems associated with transition steps to the market economy.

*) Institute of Integration of the Czech Republic into the European Union and World Economy, University of Economics, 4, W. Churchill Sq., CZ - 13067 Prague 3 (e-mail: marie.vavrejnova@cerge-ei.cz).

${ }^{\star *}$ ) Institut für Sozial - und Wirtschaftswissenschaften, Weingartshofstraße 10, A - 4020 Linz (e-mail: Belabed.E@ak-ooe.at).

${ }^{\star * \star}$ ) Kammer für Arbeiter und Angestellte für Wien, Prinz-Eugen-Straße 20-22, A - 1041 Wien (e-mail: mk.woerister@aon.at). 
A great lot of discussions, works, proposals, and also practical measures were accomplished in the course of pension reforms preparations. Nevertheless, the overall pension system is far from being completed.

This study deals with the current situation of the old age pension system, how to counter the growing difficulties of current situation, and how to build a new system, corresponding to the current and future needs of the society. The second part is dedicated to general aims of pension reforms, and general features of these reforms which are the matter of discussions both in this country and at international level. The public-private system is introduced with special attention to different types of private pillars of the pension system. The problem of mix of different systems is mentioned. The role of society aging is discussed.

In the third part pension systems and their recent reforms in the Czech Republic and Austria is described and compared, and the future of pension reforms in both countries is introduced. Both similar and different features of pension systems of the compared countries are mentioned. In the fourth part the conclusion and lessons which can be drawn from the pension reforms in the Czech Republic and Austria are introduced.

\section{Pension Reforms' Point of Departure}

\section{1 The Aim of the Reform}

When we talk about pension reform, we must have in mind first of all the aim of the intended reform. The main reason, which is introduced in discussions, mainly unfavourable demographic development, leading to the aging of the society, which under conditions of PAYG system, and together with further circumstances, causes budgetary constraints and consecutively growing deficit of public budgets, is a very important factor, which requires urgent measures. But this factor itself provokes discussions and creates more a challenge than threat for the society (see Bovenberg and Linden, 1997). The general ground of pension reforms must be in fact more profound, and cannot be confined only at society aging and fiscal problems. We must have in mind a general aim which is: creating step by step a modern system which will promote the improvement of the living standard of old generations. If we have in mind this general aim, we must work on our pension reforms in broader socio-economic relations, particularly with regard to the development of economic activities and especially to the development of labour market. In fact, the satisfactory living standard of the elderly should be prepared in the course of the whole working life of a man and the relevant social policy must support this task.

Retirement is one of main milestones in the human life. Together, it has different meaning for different people. On the one hand, medicine describes many cases of stresses or even shocks from retirement, on the other hand, many workers, especially arduously working, wait for it with eagerness. It depends on profession or employment, on whether it concerns men or women, on health conditions, etc. A modern pension system must be flexible enough, to allow a man the choice of possibilities how to organize his own old age. This is very complex task, which embraces not only growing pension benefit. The income of a pensioner should create a portfolio, consisting of pension benefit of different types, of labour income so long it is possible and desirable for him, of assets income, or of property, lowering the needed sum of pension benefit (ownership of a flat, for instance). It means that together with proper pension reform different measures for employment of elderly must be realised, the information and education of people (not only of the elderly, when it is already late) must be organised to bring people to the understan- 
ding that their living standard in old age is prepared for a long time during their working age, to learn them how to save, how to change the structure of consumption and the way of living at all, to reach the adequate portfolio of income in the old age. Especially in post-communist countries, where people were not accustomed to invest (and also had not enough possibilities to do it), this is a very topical and at the same time very difficult task.

Pension reforms thus concern not only pensioners, but the whole society:

- main parameters of pension system ought to be capable to supply the standard of living for the growing number of pensioners. At the same time the active part of the population could not be burdened overly with taxes and contributions, especially in case of families with children;

- fiscal measures connected with pension reform should not non-adequately rise the price of labour force, what could run down the competitiveness of firms;

- pension funds, both public and private represent a tremendous amount of financial means, which must be inspected to shelter the money of depositors. The security of pension money is connected with good functioning and monitored banking system and financial market.

To find a right equilibrium among all elements of pension system is a never ending process. Unfortunately, the process of reforms is subordinated to political bargaining, and politicians as a rule, quarrel rather than co-operate, what hampers the work on reform. Creators of pension reforms should seek a platform for finding consensus of political forces in decision - making process of pension system. The international experience (Sweden, Spain) has shown that political consensus and the non-partisan compound of expert teams, working on pension reforms, is very useful.

\section{2 Main Features of Pension Reforms}

Serious discussions about pension reforms begun already in the eighties. Studying the infinite volume of information about pension systems, offered by international organizations (OECD, WB, ILO) and by different groups of experts from many countries we have found that practically, in spite of some mutual general features, there are as many different pension systems as there are countries where they exists. (At the same time we cannot forget that the majority of the world population have not yet any social security!) This diversity is given by different conditions of each country: different history, different social, economic, demographic, and political development. Therefore, there does not exist for any country a ready model that could be used in implementing pension reform. Besides, we cannot expect that an ideal, once for ever given system, could be created.

At the beginning of the prolonged and broad discussions about pension reforms there existed substantially different points of view of different international organizations and expert groups with two strong marked positions, influenced mostly by political and ideological factors:

- to build and maintain a system of social cohesion and solidarity (to maintain and only reform classical public PAYG pension system),

- to build a system of individual responsibility and individual risk (to build fully funded system).

The development and especially the practical pursuance of pension reforms opened problems and risks connected with both public and private pension systems and have brought closer together these extreme positions. This has been reflected also in standpoints of international organizations dealing with pension reforms. It became clear that in a modern society an appropriate combination of both systems 
should be looked for. The difficulties and risks of both PAYG and funded system logically led to the concept of mix, whose main preference would be the diversification of risks. This concept is the basis of multi-pillar pension system. Therefore, at present the prevailing opinion about pension reforms speaks in favour of a gradual shift from pure PAYG system to a multi-pillar scheme.

The origin of the theory of multi-pillar system came from Switzerland. Today the capital accumulated in the Swiss pension funds has been converted into an annual pension that corresponds to about $35 \%$ of earnings and together with the public pillar a worker with average wage would retire with a replacement rate of $60-70 \%$. It means that the pension benefit is in average composed from $50 \%$ of public and 50 $\%$ of private sources. At the beginning, the multi-pillar system was not introduced as a reaction on aging of the population (see Queisser, Vittas, 2000).

In general, the principal advantage of the multi-pillar system supposed to be the risk diversification, because every type of pension system has its risks, of course of different kinds, and in each country of different level. The most difficult task of all pension reforms is just to acknowledge well the starting conditions and find the right time and mix. The multi-pillar public-private system should ideally comprise three pillars (their characteristics here we quote from one of the latest OECD publications):

- "the first, as a part of social security system, without constitution of large reserves;

- the second are supplementary pensions provided collectively by firms or socio-professional groups. It aims to provide a deferred income in addition to the first pillar which offers a partial replacement of earned income. These pensions are usually funded. The participation may be voluntary or mandatory;

- the third which consists of all the savings put aside by an individual for his/her old age" (OECD, 2000, p. 231).

Of course, this definition of multi-pillar system is all too general and says nothing about the role of it in current pension reforms in individual countries. The main question and at the same time the main difficulty is how to introduce private pillars in real life, what combination of the three pillars to chose, and how to change their shares in the course of further development of pension system. This depends also on introducing either voluntary or mandatory private pillars and of given share of the first pillar. The wariness and deep analysis of the incipient situation is necessary.

The classical public (PAYG) system is in general explicit and homogenous (the pension benefit is paid from current contributions and in case of lack of these means the deficit is covered from other taxes as income of state budget). But as a rule there occurs a scarcity of public means. At this moment the risks of public pension system develops: the negative balance of pension account and public budget grows: the promised evaluation of pension benefit cannot be kept, the growth of pension benefit is insufficient in relation to growing costs of living and the standard of living of pensioners is stagnating or even falling. This is the case especially in transition countries (e.g. the case of the Czech Republic, where during ten years in the nineties there was not reached the real value of pension benefit from the year 1989). But the scarcity of means for covering pension benefit has occurred also in developed countries with rich pension systems, or just due to too rich systems. In this moment economical measures are unavoidable, beginning with the parametrical and institutional reforms of the public pillar, and continuing with reforms in direction of creating the multi-pillar system.

The concept of the private system is various and may invoke some misunderstandings. It covers a number of schemes that differ in terms of the structure of the system as well of the financing used. They have a common purpose, namely to sup- 
plement social security benefits. Up to now, many studies and discussions on categories of private pension systems and their performance were published. Nevertheless, we can meet many opacities and inaccuracies in classifications and sorting the different concepts of private and public pensions. In our opinion one of them can be found already in the general definition of the private pension scheme, introduced above: in case, when the second pillar is voluntary, what is the difference between the second and third pillar? We introduce this kind of opacity because it influences the concept of pension reform in the Czech Republic, that will be discussed in the third part of this study.

Whereas a great deal of discussions and publications is dedicated to the private funded pension systems, practical measures of pension reforms, especially in European countries, have carried out as parametrical improvements of the public pillar, because here still many reserves have been found, especially in increasing the retirement age, increasing the number of years of contributions, raising the age and minimum years of work for early retirement, increasing the reward for working longer and others.

Some conclusions to so far characterised main features of the pension reforms. Both public and private pension systems deal with great amounts of longterm money. At the same time both systems are far from being satisfactory from the point of view of tasks they have to solve:

a) PAYG system seems to be able to provide in the future only limited pension benefits. The improvement (parametrical and institutional) of the public pension system would contribute to suppression the uncertainty of the future of it. In the moment, when all reserves of the public pension system are exhausted, the increase of contribution becomes necessary. The negative consequences are well known. This is not only the question of the effect of higher taxes. It is also the question of the degree of the solidarity between generations, which is not limitless.

b) The introduction of the second pillar (in correspondence with our conception we have not in mind the voluntary system) is complicated, among others because its proclaimed advantages are substantiated more theoretically than bringing concrete evidence about results, especially about rate of return of the capital. In connection with it there is necessary to mention a very important theme dealing with the ethics of investment's character (see Belabed, 2001). The second pillar is financially risky from many points of view because of economic and social development as well as the lack of foresight on the part of individuals. We can hint at the case of so far prosperous Dutch occupational second pillar, which is very large and whose amount exceeds the country's national debt. It has been highly threatened by falling prices of shares, in which the pension funds invested the money of their clients. For many Dutch pension funds the funding for this reason has dropped to below 100 per cent and it requires drastic adjustments to pension contribution rates (see Ewijk, Ven, 2003). Recently the scandal with Enron (USA) has been often mentioned. Besides, the whole system of benefit defined pension funds of the USA have occurred at present in great deficit and calls for reform. The introduced facts show that a great share of private pillar in pension system may be so far dangerous for their clients. Many serious measures must be constituted to support the positive results of the second pillar, namely:

- the containment of bankruptcy risk of firms,

- the system of supervision and monitoring the activities of the firms and funds dealing with worker's money,

- the system of controlling fees for funding pensions, and compare them with those of public pensions (more details see www.worldbank.org/pension). 
A special situation nowadays exists in countries in transition, where the difficulties of transition period have caused a great lack of financial resources due to decrease and tardy development of economic activities. That is one of the reasons why these countries look in addition to public means for further financial resources for pension systems and their governments have been disposed to realise the private pillars. But there must be taken into consideration the fact that in these countries the people were accustomed in the past regime to a great degree of income equality and the introduction of second and third pillars in pension systems while shortening substantially the first pillar could cause the excessive growth of income inequality among the elderly and raise the poverty among them. Furthermore, the banking sector and financial institutions in these countries are yet not strong enough and this situation would cause a lack of confidence in the security of contributions to the private funds.

Discussions on advantages and risks of different types of pension systems continue. The main proponent of the shift from the PAYG system to the private funded system, is logically the World Bank (WB), providing loans and technical support to many countries. On the other hand the International Confederation of Free Trade Unions hint at many deficiencies of the funded system as compared to the PAYG system (see Baker, Kar, 2003). Unfortunately, these discussions suffer from lack of facts and lessons of different countries' experience. Especially the information about returns of private pension funds is poor and only the cases of exceptional events are published. Here we introduce as an example some figures on average real returns on pension portfolios in some countries. The data are unfortunately somewhat outdated, because at present the situation in many countries has been changed.

Table 1

Average Real Return on Pension Portfolios (1984 - 1998, in per cent of assets)

\begin{tabular}{|l|c|l|r|}
\hline Belgium & 10.33 & Netherlands & 9.64 \\
\hline Denmark & 6.14 & Switzerland & 4.90 \\
\hline Germany & 6.72 & United Kingdom & 10.35 \\
\hline Ireland & 12.54 & United States & 10.49 \\
\hline
\end{tabular}

Source: WB, 2000, source of date: European Commission, 1999.

\section{3 The European Pension System}

At present, still about $80 \%$ of retirement benefits in European countries are provided by public PAYG systems (see Robinson, 2001) which are in most European countries by far the most important source of retirement income. The scarcity of financial resources of public budgets, and especially the future impact of aging of the society - which is in European countries the most marked feature of the demographic development in comparison with other regions of the world - have forced many countries with quite generous PAYG systems, such as Germany and Austria, to launch reforms aimed at lowering payments from public pension systems and strengthening supplementary, funded forms of financial provision for old age. The European countries prefer occupational form of second pillar, and it has have in some countries a long tradition. Moreover, the majority of them are members of defined 
benefit schemes. Here we introduce the overview of the share of population in active age participating in pension funds in some European countries.

Graph 1

Participants in the Pension Funds in \% of the Active Population in 1998

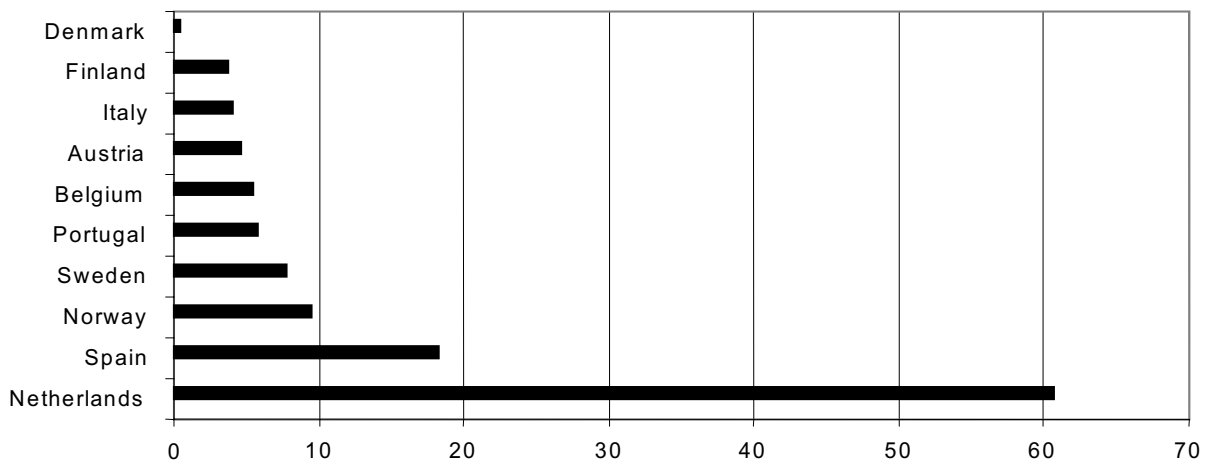

Source: Kalliauer, 2001, p. 9.

The exceptional position of Netherlands and difficulties of the funds were already mentioned.

The old age dependency ratio (the ratio of people aged 65 and more to the population at the working age) is doubtlessly growing and will grow. The projection of this ratio in the EU 15 Member Countries shows a sharp increase in the future: in 2000 it reached $26.7 \%$, in 2020 and 2040 it is projected to reach $35.1 \%$ and $52.4 \%$, respectively.

The demographic development and the situation on the labour market is considered to be the main factor determining the inevitable changes in public pension systems. However, the steadily increasing life expectancy is one of the most positive factors of a society development. The growing age means that also the active age is growing. It is clear that the present sexagenarian is younger than that 20 or more years ago. Besides, the old people will be more and more educated, with more knowledge, experience and information. (In connection with it there must be also taken into account that people come into working process later, due to longer time of education.) These are the reasons for prolonging eligibility age and for facilitating to pensioners or people in pension age to find or to change work places.

In many discussions about pension reforms we can hear voices pointing out to the underrating of the importance of the labour productivity growth in compensating the deteriorating age structure of the population. The factor of growing productivity of labour means that less active population can sustain a greater number of pensioners what can serve as substantiation of sustainability of the PAYG system. Together with growing productivity of labour and appropriate growth of wages the amount of social contributions as the source for public pension financing increases. But here emerges also the question of the income redistribution among generations as the result of growing labour productivity. In other words, what share of the result of growing labour productivity is the working generation and the state willing to part with the retirees - what will be the relation between growth of wages and growth of pension benefits? In any case, more attention must be paid to this factor by modelling pension reforms. 
The European Economic and Social Committee ${ }^{1)}$ (ESC) supports the first pillar and recommends that Member States look for ways of improving its stability. The pillar one regime objective to ensure universal entitlement must be safeguarded, the European Economic and Social Committee would not endorse watering down pillar one and a general shift towards private schemes (see ESC, 2001/1). The Committee also points out that a switch from the PAYG system to funded pillars needs financial means and that initiatives to develop the second and third pillar have to make sure that obligations concerning payments within the first pillar are not at risk. In this context, the Committee also underlines the need for high quality, comparable indicators and reliable statistics when evaluating existing systems and designing their future development. Raising participation rates, building reserve funds, supplementing state pensions with funded top-up schemes, adapting pension schemes to changing employment patterns, reducing public debt or a combination of these factors can in opinion of the ESC contribute to improving the sustainability of PAYG systems.

All these activities have different economic and social implications and we have to consider them carefully. Some of these are outlined further.

To achieve the goal of raising participation rates, a combination of favourable macroeconomic conditions and sustained reform measures is needed to promote growth and employment like an age-aware personnel policy, tax incentives for employers to keep on older workers, part-time employment of the pensioners, tax incentives for employees to stay in work longer, flexible pension arrangements. Further, raising female participation rates, which of course requires the reconciliation of family and career needs.

Statistical data, although they are not quite complete, show that in most of European countries the participation rate is growing (with exception of Austria).

Table 2

Employment Rate by Age Groups (in \%)

\begin{tabular}{|l|l|l|l|l|l|l|l|l|}
\hline \multirow{2}{*}{ Aged } & \multicolumn{2}{|c|}{$15-64$} & \multicolumn{2}{c|}{$15-24$} & \multicolumn{2}{c|}{$25-49$} & \multicolumn{2}{c|}{$50-64$} \\
\cline { 2 - 10 } & 1995 & 2000 & 1995 & 2000 & 1995 & 2000 & 1995 & 2000 \\
\hline Men and Women & 59.9 & 63.1 & 37.2 & 39.9 & 74.3 & 76.8 & 46.6 & 49.4 \\
\hline Women & 49.7 & 53.8 & 34.1 & 36.5 &. & 67.2 &. & 38.7 \\
\hline
\end{tabular}

Source: Eurostat, Yearbook 2002.

As a rule, the rate of employed women is lower and there is a North-South divide in the rate of women in the working population: in Greece, Spain and southern Italy there are the lowest percentages, whereas in Netherlands, Sweden and United Kingdom they are the highest. This North - South divide exists partially also in the total rate of employment. The European Council (Lisbon, 2000) set as a strategic goal to achieve a total employment rate of $70 \%$ by 2010 and at the Stockholm

1) The European Economic and Social Committee is one of the EU institutions set up by the Rome Treaty; it is composed of representatives of the organized civil society (employers, workers, various interests) in the Member States, its task is to advise the Council, the Commission and the Parliament, to cooperate with other institutions and to build the bridge between the European institutions and organized civil society. 
Summit 2001 an intermediate goal was stated: the total employment rate should reach $67 \%$ by January 2005 .

In the Czech Republic the total participation rate was $60.3 \%$ in 2000 , that of women $51.6 \%$. Both figures are somewhat smaller than those of the EU 15. (For the rate of employment by age group in European countries separately see Eurostat Yearbook, 2002, pp. 100-103, for the Czech Republic see Statistical Yearbook of the CR, 2002, pp. 692.) The positive development of participation rate would contribute as one of factors to the sustainability of PAYG system.

European Commission is concerned with the possible consequences of increasing social contributions: among others effects, it increases the cost of employment and is thus potentially in conflict with the aim of increasing labour force. This effect can be countered by taking the total value added created in companies as a basis for employers' contributions instead of wages alone. This would also adapt contributions to structural development of the economy.

The design of pension systems as such was not a part of the acquis to be taken over by candidate countries for accession, but the question is very intimately joint with the labour market problems, especially with the labour force migration, and in connection with it, it will be necessary to harmonize in the future also the pension systems to a certain extent. At least, the interchange of experience among countries is needed.

In the next part of this study we try to compare main features and mutual problems of pension reforms in two countries, Austria and the Czech Republic.

\section{Pension Reforms in Austria and in the Czech Republic}

Austria and the Czech Republic are countries situated near to each other, with a similar territorial size and similar number of inhabitants. These two countries have intensive trade and also occupational relations, what will doubtlessly impact also their pension rules in the future. In spite of different stage of economic development (the economic level of the Czech Republic has reached less than $55 \%$ of the Austrian level, measured in the gross domestic product (GDP) per capita, based on the current purchasing power parities), and in spite of far more rich pension system in Austria (the share of expenditure on public pensions reached in 2000 in Austria $14.5 \%$ of GDP, the share in EU 15 was $10.4 \%$ and in the Czech Republic it was $9.1 \%$ ) the problems of pension reforms are in many cases very similar and therefore the comparison of their handling should be useful.

\section{1 Present Situation in Selected Parameters of Pension System in Both Countries}

To characterise the situation of both countries we use the following parameters:

- aging of the population,

- growing dependency ratio,

- changing participation rate of the population.

The situation concerning aging in Austria and the Czech Republic. The Czech and Austrian demographic development does not differ very much from the European one. During the nineties, the population of the Czech Republic was stagnating, speaking more precisely, it was even decreasing (10.363 million in 1990; 10.283 million in 1999 and 10.298 million of inhabitants were recorded in the last census of the population in the first quarter 2001 with the number of deaths stea- 
dily decreasing from 129.2 thousand in 1990 to 109.8 thousand in 1999. On the other hand the infant mortality rate is together with Slovenia, the lowest among the new EU Member States (5.2\%). Also, the net migration is positive. In this situation, the quickly decreasing number of births is the main factor of the society aging. (The number of live births was 130.564 thousand in 1990 and 89.471 thousand in 1999.) Therefore the growth rate is negative $(-0.1 \%)$. In combination with the individual aging, i.e. the steadily increasing life expectancy, the share of the older age groups in the population grows and shapes the dependency ratio (the ratio of the population aged $65+$ to the population group aged $15-64)$. Even though the share of the elderly in the Czech Republic is currently lower than in most of the European countries (in 1998, the average share of people aged 65 and more reached $16.2 \%$ of the total population in the EU 15 and $13.7 \%$ in the Czech Republic - see OECD in Figures, 2001), demographic projections envisage a high increase of this share in the future.

Table 3

The Age Structure Development and Projection in the CR (in \% of the total population)

\begin{tabular}{|l|l|l|l|l|l|l|l|}
\hline Age & 1980 & 1991 & 1995 & 2000 & 2010 & 2020 & 2030 \\
\hline $0-14$ & 23.5 & 20.6 & 18.3 & 16.2 & 13.7 & 13.7 & 12.4 \\
\hline $15-64$ & 63.2 & 66.6 & 68.4 & 69.0 & 70.2 & 64.7 & 63.5 \\
\hline $65+$ & 13.3 & 12.8 & 13.9 & 13.9 & 16.1 & 21.6 & 24.1 \\
\hline
\end{tabular}

Source: CSO, 2001, Projection: Statistical Yearbook of the CR 2000, median version, p. 123.

On the contrary, the Austrian population is slightly increasing (it was 7.624 million in 1989 and 8.092 million in 1999). The growth rate $1999 / 1989$ was $0.2 \%$. In the same period, there was a different percentage of foreign population: in Austria it increased from $5.1 \%$ of the total population in 1989 to $9.2 \%$ in 1999 , which is the third highest percentage in Europe, following Luxembourg and Switzerland. In the Czech Republic, the relevant percentage was $0.4 \%$ in 1992 (there are no data for 1989 ) and $2.2 \%$ in 1999, one of the lowest in Europe.

Table 4

The Age Structure of the Population (in \% of the total population in 1998)

\begin{tabular}{|l|c|c|c|}
\hline Age structure & under 15 & $15-64$ & 65 and more \\
\hline Austria & 17.1 & 67.5 & 15.4 \\
\hline Czech Republic & 17.2 & 69.1 & 13.7 \\
\hline
\end{tabular}

Source: OECD in Figures, 2001.

The main problem of society aging is not the growing life expectancy, but decreasing number of birth. At present the falling share of the group aged 0-15 means that the society needs less money to help families with children and families without children can save money for themselves instead of use it for child upbringing and education. But in the future this situation will shorten the active part of the population and decrease the amount of contributions, it means the amount of sources for pension system. The often discussed role of immigrants in improving the age structu- 
re of the population is not unequivocal. Analyses show that it can be both positive and negative, depending on the character of immigration: the experience of Germany shows that immigrants leave often children at home, then return home and there only remains the duty to pay pension benefit to them. Such immigration does not contribute to slowing down the aging, therefore meaningful and useful form of immigration is a difficult task of the migration policy.

Growing dependency ratio. The ratio of people aged 65 and more to the population at the working age is doubtlessly growing and demographic projections show a sharp increase in the future. The projection of the Czech statistics shows similar trends in old age dependency ratio - median variant, but a more optimistic (if we compare the data for 2030 with the Austrian ones).

Table 5

Future Development of the Dependency Ratio (in \%)

\begin{tabular}{|l|c|c|c|c|c|}
\hline & 2000 & 2010 & 2020 & 2030 & 2040 \\
\hline $\begin{array}{l}\text { Austria aged 65 and more } \\
\text { to those aged 15 - 64 }\end{array}$ & 25.1 & $\cdot$ & 32.4 & 43.6 & 54.5 \\
\hline $\begin{array}{l}\text { CR aged 65 and more } \\
\text { to those aged 15 - 64 }\end{array}$ & 22.8 & 23.0 & 33.4 & 37.9 & \\
\hline $\begin{array}{l}\text { CR aged 60 and more } \\
\text { to those aged 15 - 59 }\end{array}$ & 28.3 & 37.6 & 48.2 & 56.9 & 75.6 \\
\hline
\end{tabular}

Source: Statistical Yearbook of the Czech Republic, 2000, p. 123.

The introduced numbers are not quite comparable due to different years of statistical data, but the trend of development is the same. The second row of Czech data and also the following graph show how the present low eligibility age strongly influences the dependency ratio and contributes to the necessity to prolong it. But demographic projections are being currently specified and for instance the Austrian development is to date more optimistic. Instead of a decreased number of the population the recent projections are assuming the growth. During the eighties and nineties the dependency ratio in the CR remained unchanged, at about $20 \%$, but in the future it will remarkably grow.

Graph 2

Growing Dependency Ratio in the CR (in \%)

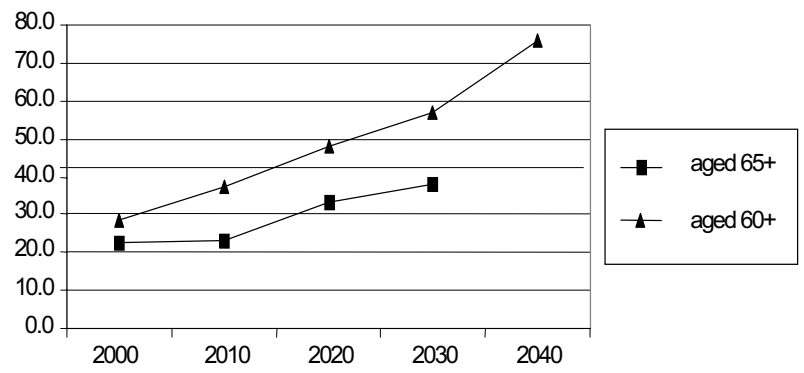

Changing employment (participation) rate. In all EU 15 countries the total participation rate of population aged $15-64$ during $1995-2000$ was growing, with 
exception of Austria and also the Czech Republic. But looking at the figures we see that the participation rate in Austria was remarkably higher than that of the EU 15 average which was $59.9 \%$ in 1995, 63.1\% in 2000, and in Austria $68.4 \%$ and $67.9 \%$. The corresponding data in the Czech Republic were $61.5 \%$ and $60.4 \%$, near to EU 15 average (see Eurostat Yearbook, 2002, pp. 100, 101, 315; here we can find also the information about changing rate of participation of women, which increases in all countries including Austria, but not in the Czech Republic, where it was one of the highest in the past and now it is on the level of EU average).

The participation rate of elderly is logically sharply decreasing with the growing age in all countries. But Austrian participation rate of elderly is considerably lower than the average in the EU countries (on the 12 place among 15) and it is also more decreasing with the growing age. Lower participation rate is in this case doubtlessly connected with the so far existing conditions of early retirement. The participation rate of the Czech elderly is on the European average, but then it is also quickly decreasing in connection with present low eligibility age.

Table 6

Participation Rate of the Elderly in 2001 (in \%)

\begin{tabular}{|l|c|c|}
\hline & In the age of $55-64$ & In the age of $60-64$ \\
\hline Austria & 28.6 & 14.0 \\
\hline Czech Republic & 38.9 & 18.2 \\
\hline EU 15 average & 38.8 & 23.4 \\
\hline
\end{tabular}

Source: Yearbook Eurostat, 2001.

Here the negative influence of the high degree of early retirement on participation rate in both countries should be mentioned.

Often we can hear an argument that there is a conflict between demand for work from the side of the unemployed and that of pensioners and therefore the prolonging eligibility age for pension is not meaningful. But there does not exist a direct relation between the demand for work of the unemployed and that of the elderly (different structure of work, different regions, rules regulating the employment termination, etc). It is the matter of good employment policy, looking for an adequate structure and form of job places (half time employment for the pensioner, schooling them, stimulation of the employers to give work to the elderly, e.g. with tax incentives, etc). This is of course an optimistic point of view. Worsened economic situation might push away the elderly from the labour market.

Unemployment itself in every case influences the pension balance negatively: the amount of social contributions decreases and the need for social support grows. This factor influences especially the Czech balance: recently, the rate of unemployment has reached $10 \%$. Taking into account the average amount of contributions and the number of unemployed, we can find that if we succede in reducing the unemployment rate to $5 \%$, the deficit of pension balance would be lower by $50 \%$ only on account of relevant growth of contributions.

Negative development of introduced parameters has caused in the last years the growing deficit of public finances and of pension budgets in particular, both in Austria and the Czech Republic.

The development of introduced parameters both in Austria and in the CR testifies the urgency of reform measures, overlooking the fact, that Austrian pensions 
Table 7

Balance of Pension Budgets (income minus expenditure)

\begin{tabular}{|l|c|c|c|c|c|c|}
\hline & 1995 & 1996 & 1997 & 1998 & 1999 & 2000 \\
\hline Austria (ATS mil.) & $-1,033$ & $-1,024$ & -575 & -692 & -891 & -849 \\
\hline CR (CZK bill.) & 7.0 & 5.6 & -5.1 & -10.1 & -16.4 & -16.7 \\
\hline
\end{tabular}

are much richer than the Czech ones, correspondingly with the higher economic level. The share of public pension system expenditure in GDP in Austria was in 2000 the highest among European countries, namely $14.5 \%$, the EU 15 average reached in the same year $10.4 \%$, and that in the Czech Republic $9.4 \%$. The average old age pension benefit in the Czech Republic was in 1997 at the level of $36 \%$ of the Austrian one, in comparable PPP's USD, when the economic level of the CR was more than 50 \%, measured by comparable GDP (more see Vavrejnová, Wörister, 2002).

The collection of factors influencing the pension balance would not be complete if we do not mention the rate of social contributions. There is a remarkable difference between Austrian and Czech structure of paid social contribution: the whole rate is similar (about $34 \%$ ), the rate paid by employees and employers in Austria is nearly the same $-17.0 \%$ and $17.1 \%$ - in the Czech Republic it is for the employers $26 \%$ and for the employees $8 \%$. This difference is hardly to be substantiated. The high share paid by employers can support the unemployment. On the other hand the increase of the share of employees would lower the net wage, and the increase of the contribution rate as the source for pension benefit is not desirable from the point of view of labour cost. Therefore, the both countries do not intend to higher the contribution rate as a whole.

\section{2 The Conception of Pension Reforms}

The scenario of pension reforms in both countries is similar:

- most of the attention has been devoted to parametrical reforms of public (PAYG) system. Both countries intend to realise a more profound reform of PAYG system - to pass from the benefit-defined scheme to the notional-contribution scheme;

- in both countries the third pillar (voluntary reinsurance and life insurance) has been successfully developing;

- the second pillar in the Czech Republic is the matter of discussions, whereas Austria has already long-term experience with the occupational pension system (Pensionskassen).

It is necessary to add that different kinds of prepared and pursued pension reform measures do not touch the present pensioners. These only could bear the risk of lower valorization of pension benefit if the state does not want or is not able to realise given promises. On the other hand they can make - and really make - use of voluntary savings in the framework of the third pillar. Let us compare the reform measures in more detail.

\section{2. 1 Parametrical Reforms of the PAYG Systems}

Each country has both similar and different kinds of reserves which can be utilise to improve the conditions of the PAYG system. 
The eligibility age. The eligibility age for an old age pension is higher in Austria - till 2000 there was 65 for men and 60 for women, with a possibility of an earlier pension at age of 60 and 55 respectively, of course under some conditions. However, the possibility of taking advantage of the early retirement resulted in a remarkable decrease in the actual age of retirement and the needs for benefits consequently increased drastically. Therefore the reform measures since 2000 have changed these parameters (see below).

In the Czech Republic the eligibility age was lower than in Austria - one of the lowest in Europe and other countries of the world (Canada, Australia, USA): 60 for men and 55 - 59 for women, depending on the number of children. Recently it was adjusted upward every year by two months for men and four months for women. It should continue until the year 2007 when the eligibility age for men would be 62 and $57-61$ for women. (But the last proposals are 63 years both for men and women what should be reached in 2010.) The same eligibility age for man and women exists in most of developed countries even today.

Early retirement. The problem of early retirement exists in both countries and conditions for it were tightened up in the course of reforms. In Austria the early retirement age has been step by step increased and the discount rate raised (see below). In the Czech Republic the situation is worst due to recently increased rate of unemployment, which caused in many cases in selected regions the involuntary early retirement. From this point of view conditions on the labour market are in the Czech Republic and Austria different. Recently, the unemployment rate in the Czech Republic increased and is about $10 \%$, in Austria remained on a low level (in 2002 it was $4 \%$ ).

Increasing women employment. In Austria there are some reserves in this field, because the participation rate of women, especially in the higher age group belongs to the lowest among European countries. This is not only the question of increasing the amount of contributions, but improving the position of women both in work income and pension benefit. Due to historically low participation rate of women in Austria together with high share of part-time employment of women their situation in pension age is worse than in the CR, where during the old regime a very high share of women employment existed, better said over-employment from the point view of family life. Therefore, under new conditions this share has decreased a little, nevertheless it remains high.

Different pension systems for some professions. This is another reserve in the Austrian pension system. For historical reasons, the majority of civil servants, a part of railway employees, and also employees in mining have notably higher pensions and other advantages. The prepared unification of pensions for all professions is a hard task of the reform. Nevertheless, the realization of it is to be expected very soon. Only arduously working employees will get in the future the possibility to retire sooner. (But there is not yet defined what kind of work is supposed to be arduous, what must be done before introducing new rules.) The Czech pension system is uniform for all kinds of professions. All exceptions were cancelled during the first half of the nineties. However, was it really necessary to unify the eligibility age also in case of arduous professions? This question will be perhaps resolved in the course of further reform measures, as in Austria.

The pursuing reforms of the Austrian PAYG system. Major reforms were introduced in 1993, and in 1997 as part of the 1996/97 fiscal package, and again in 2000. In the budget consolidation package 1996/1997 the federal government took additional steps to discourage early retirement by raising contributory periods and the discount rate in case of early retirement. Furthermore, it introduced the requirement to purchase (previously free) month of education to count towards retirement, 
own contributions for rehabilitation and stricter deduction rules for double pensions and simultaneous pension and work incomes.

The 1997 reform comprised, as major elements, the extension of the benefit assessment period from 15 to 18 years in case of early retirement, the introduction of the uniform increase of the replacement ratio by two percentage points per contribution year and a discount of two percentage points per year in the event of early retirement. Moreover, the eligibility criteria for early retirement due to lack of fitness to work were tightened. The benefit assessment period, phased in till 2019, and the annual pension adjustment for civil service retirees were harmonized with the general schemes. The degree of self-coverage in the pension schemes for farmers and self-employed was increased. Insurance coverage was extended to low part-time incomes. More favourable conditions for gradual retirement and a better accounting for child-rearing years completed the reform.

The reform, coming into effect on October, 1, 2000 increased all early retirement ages by 1.5 years until 2003, in the general scheme from 55 to 56.5 for women and from 60 to 61.5 for men. In case of early retirement, the discount rate was raised from two to three percentage points of the contribution base per year up to the maximum level of 10.5 percentage points in the private sector and of 18 percentage points in the civil service schemes. When working longer than 60 and 65 years, a supplementary bonus to the pension benefit of 4 percentage points of the contribution base per year up to the maximum level of 90 per cent of the contribution base will be granted. Supplementary measures for old age workers will be introduced with the primary objective to counter harmful side-effects of the pension reform on the labour market for older workers. The pension contribution by active civil servants and civil service retirees was raised by 0.8 percentage points.

The reform of PAYG system continued in 2002 and 2003:

- continuing to higher the age for the early retirement and also to higher every year the amount of deduction. Fundamentally, the early retirement would be gradually left off definitively to 2013. The persons who have payed contributions for 40 years - women and 45 years - men, can receive early retirement up to 2007, but with a reduction;

- reduction of widow and widower pensions by persons with high mutual incomes;

- removal of the abridge of pension in case of simultaneous employment, to support the employment of the elderly.

Further changes of PAYG system have been proposed by the Commission for the pension reforms with the future aims:

- instead of fifteen best years as a basis for pension benefit assessment, to calculate all incomes. This measure would shorten the pension benefit at about $25 \%$;

- to introduce pension accounts (to exploit the Sweden and Italian experience);

- to improve the position of women in their own pension insurance;

- to increase the evaluation of the time of the children nurture;

- to reduce the widow pensions.

The governmental proposals include yet more progressive changes (see www.austria.gv.at):

- to shorten new pensions to the year 2028 by $30-40 \%$;

- to remove early retirement to the end of 2009;

- to reduce social contributions for old employees;

- to initiate the right of schooling for young and elderly unemployed.

These proposals have been criticized from the part of trade unions and the Kammer für Arbeiter und Angestellte. The reduction of pension benefit seems to be too strong. The removal of early retirement will cause the growth of unemployment. The 
proposals will cause a great reduction of women pension benefit, because the parttime employment (which prevails by women) will not be counted.

Because of political character of proposed reform measures, it will be difficult to realise them. The unprecedented protests of the public against reform proposals in Vienna in 2003 hint at the fact, that anyhow rich the economy and the pension system is, nowbody wants to lose already acquired advantages, regardless of the fact that they could be threatened in the future if the reformatory measures are not realised. Due to protests some of proposed measures were already changed: to the year 2028 the new pension benefits will be shorten only by $10 \%$, and the removal of early retirement should be realised till 2017.

The PAYG system reforms in the Czech Republic. Main problems of the public pension benefit in the Czech Republic are:

- low valorization in a long-term period (only in 2004 the pension benefit would reach the real level of 1989 , yet still the rate of replacement is $57 \%$, in comparison with Austria where it reaches $79 \%$ of the net wage). But it may be that the rate of replacement in both countries will not grow and even will decrease due to reforms of the PAYG system (see Graph 3);

- great egalitarianism, which existed in the old regime and even grew during the nineties due to method of calculation and valorization of pensions is another problem of the Czech public pension benefit. Statistical data show the decrease of differences between the values of the lowest and highest ten per cent income in households of pensioners, in comparison with the remarkable increase of these differences in the households of employees, which confirms the difference between quickly growing wages and stagnating pension benefits.

Graph 3

The Development of Real Pension Benefit in the CR (in \%)

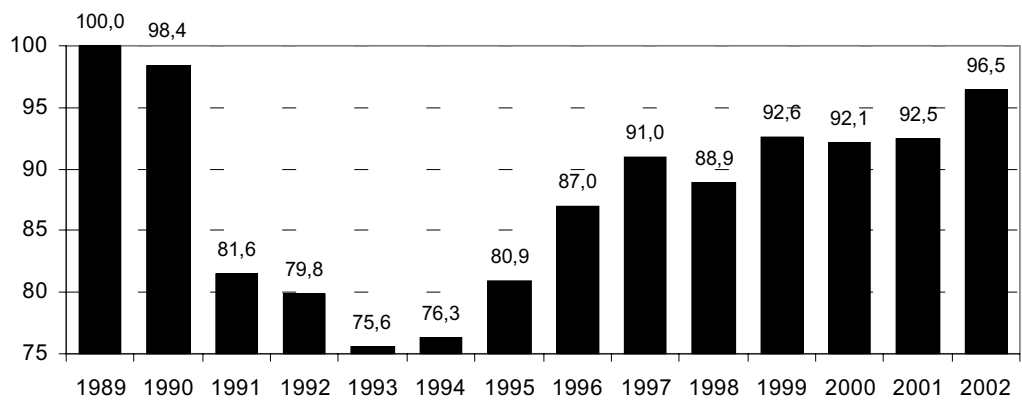

Source: Ministry of Labour and Social Affairs of the Czech Republic.

These problems are to be solved during future steps of pension reform and in the course of positive economic development, but they cannot be solved only in the framework of PAYG system reform.

Parametrical reforms of the PAYG system in the Czech Republic began in the 1990 and the first phase of reform measures rounded off with passing the Act on Pension Insurance in 1995, which enacted the main precondition for further reforms: elimination of preferences in pension system, methods of valorization, twocomponent system. In following years the parametrical reform has continued: 
- increasing the eligibility age for old age pension gradually to the year 2007. But this increase has proved to be not sufficient. It is still bellow the eligibility age of most of European and also OECD countries and therefore further changes are prepared for the future. Namely to increase the eligibility age to 63 years both for men and women (last reform projects); $1.3 \%$;

- increasing the percentage of the reduction of early retirement from $1 \%$ to

- increasing the percentage of old age pension in case of continuing employment after reaching pension age without taking pension from $1 \%$ to $1.5 \%$ for every 90 days;

- the pension benefit will receive also a person taking care of a disabled, or of a partially disabled person more than 80 years old.

Besides parametrical measures of the PAYG system a substantial change of it has been recently proposed - the introduction of the notional defined contribution (NDC) system with personal pension accounts. Comparing the Austrian and Czech reform measures of PAYG system we see many similarities:

- increasing the bonus/malus system by continuing employment after reaching pension age/by early retirement; increasing the age for early retirement and measures for reduction the number of early retirees; increasing evaluation of child care; supporting the employment of the elderly and removing restrictions in concurrence of the employment and pension. In this part of reform measures the Austrian are more concrete: the reduction of contributions for the elderly, the right of schooling for them, the help by looking for employment. The Austrian PAYG reform measures in general are deeper, what corresponds to the necessity to reduce the generosity of the existing pension system;

- there are some other reserves to improve the parameters of the PAYG system both in Austria and the Czech Republic, which are the matter of recently prepared projects. For instance both in Austria and in the CR it is considered to delete the student years from the number of working years needed for the claim to old age pension. In both countries there is a great extend of fictitious qualifying periods - which is to be restricted. In the CR it reaches $25-30 \%$ of the all involved years.

\section{2. 2 Development of the Private Pension Schemes}

Both countries' experience confirms that the classic PAYG system alone could not provide for an adequate pension benefit in the more distant future. Therefore, the development of different kinds of private insurance schemes have become the matter of discussion.

The second pillar. In Austria there exists and develops the occupational form of private reinsurance, which is organised with the help of "Rentenkassen". At present there exist 12 corporate Kassen and 7 Kassen on the higher, branch level. The property of them grew from EUR 2.3 bill. in 1996 to EUR 8.28 bill. in 2001, it means 3.6 times during five years. The number of participants in the same period increased from 126 thousand to 283 thousand and the number of paid pensions from 12 thousand to 35 thousand.

In comparison with cca 2 millions participants of the first pillar it is still a small part of employees who get supplementary means to the public pension benefit with the help of second pillar. This form of savings is voluntary. The further promotion of the capital-funded second (firm - related benefits) and third (tax favoured individual provision) pillars, linking individual contributions and benefits more closely together, and the introduction of a personal pension account is a part of further reform measures. 
In the Czech Republic a proposal of main principles of occupational form of supplementary pension insurance has been worked out by experts of the Ministry of Labour and Social Affairs in cooperation with the Ministry of Finance. This proposals aimed to ensure a supplementary income to the first pillar. The main principles were as follows:

- both the establishment of this fund by the employer and the participation in it by the employee would be voluntary;

- the fund would be an independent subject, separated legally from the employer;

- the contributors to this fund would bring both the employees and employers;

- investment of the financial means would be pursued by competent administrator, authorised to invest in capital market;

- the profit of the fund could be used only to the benefit of the employee;

- the early withdrawal of gathered financial means would not be allowed;

- the transmission of claims of the participant to another fund by changing the employer would be guaranteed. Also the transfer of means to another EU Member State has been anticipated;

- tax alleviation would be done;

- occupatinal funds would come under state supervision.

The advantages of the occupational pension funds have been pointed out in the proposals: lower administrative costs, direct participation and control of employees on the administration of the fund, etc. Nevertheless, the occupational funds cannot avoid the risks of low, and even negative results of investment in dependance on the capital market development, as it occured in the USA and Netherlands.

At present, there does not exist political concensus in the Parliament of the Czech Republic on introduction of this kind of pension funds. All disputations are held on a too general level. But there is also a great preasure from the side of financial funds which do not want occupational pension funds to be established, because they feel great competitors in them. Therefore, they are great lobbyists for their main role in private pension savings. But also the employers would hesitate to establish voluntary occupational pension funds. Today they are paying to about 600 thousand of employees a contribution to the third pillar and are hardly interested in establishing occupational funds.

The third pillar. In Austria, in the framework of further reforms in addition to its PAYG system, a new government-subsidised savings scheme was created in 1992. People, who pay up to 1,000 euro per year as a pension contribution under the private insurance or occupational pension programmes, voluntarily upgraded the statutory insurance schemes and the funds known as "pension investment funds" will be credited a government premium of $4.5 \%$ of the saved total. Investment earnings and pension benefits are tax-exempted. The share of this saving scheme is still very low, also because the minimum contribution is too high for many people (monthly at minimum euro 126.06). On the other hand, about hundred thousand of people are not insured at all, most of all women.

In the Czech Republic the government subsidised pension reinsurance was introduced in 1994. At the beginning the number of participants grew very quickly because in conditions of low interest rate of other kinds of savings, this form of savings with state contribution was the most convenient. Besides, it was possible to withdraw the savings after two years. It was clear that this form of savings had nothing to do with long-term pension savings. Therefore in 1999 the conditions were little changed - the withdrawal is now possible only after five years, and a tax benefit for the savers was introduced. To date the system has about 3 millions of participants (more than $50 \%$ of them are women), what is more than a half of employees, who use the services of 14 pension funds (this was the number of funds in 2001) opera- 
ting in the pension - and life insurance, six of them are owned $100 \%$ by foreign shareholders. The ownership of funds grew from CZK 1.2 bill. in 1994 to CZK 55.0 bill. in 2001. They are investing largely in state obligations. The costs of pension funds (fees of intermediators and advertising) amounted in 2000 to $24 \%$ from the participants contributions. Unfortunately, the age structure of participants is not favourable - the main group are people aged 50 - 59 years and younger groups of savers is diminishing. The average age of the participants since 2000 has began slowly growing. In relation to the average wage growth the average contribution is sinking and its amount is from the point of view of additional pension benefit insufficient. Discussions about the efficiency of the state subsidizing this form of savings are taking place, because it subsidizes the richer part of the population. The minimum amount of savings is not in contrast to Austrian third pillar determined. It should be added, that the housing savings scheme competes with the pension savings. But it is today in the Czech Republic the most efficient form of savings and the most efficient investment for young people. Nevertheless, it would be useful to involve young generation into voluntary pension savings. This is not only the question of state help with contributions (which might be for example higher for younger generation and lower, or not at all for older people, but also to "haunt" them, better say to inform them truthfully about their own future situation).

In general, there is a high propensity to save in the Czech Republic high number of participants of the third pillar, and traditionally high rate of savings in banks in spite of negative interest rate in the most of years of the nineties. This may be a good prognosis for the pension savings of different types, it depends only on the good pension policy. But the question is the distribution of savings among different income cohorts of the population, what should be investigated.

In the framework of the third pillar an important place takes in both countries the life insurance. In the Czech Republic there were 6.5 mill. life insurance contracts in 2002, about Austria the information says that life insurance contract has been concluded by every fourth household.

\section{3 Continuing Works on Pension Reform by Introducing the Notional Defined Contribution System}

Pension reforms in both compared countries have been inspired by the new Swedish pension system, which was introduced during the nineties. Therefore, we introduce the main principles of this system. Main ideas of the Swedish reform were published in 1992 and a package of detailed proposals of legislation was passed in 1994 and then presented for public discussion.

The universal first pillar defined benefit system was replaced by notional defined contribution (NDC) system, combined with financially defined contribution (FDC) scheme of the second pillar. Contributions based on a defined contribution rate are recorded on individual accounts. Account values represent a claim on the future pension. There is no advance funding, and for this reason this scheme is called notional defined contribution scheme. The total contribution rate of the new old-age system will be $18.5 \%$, half of them paid by the employee, half by the employer. For persons who will be fully covered by the new system 16 percentage points will go to the NDC PAYG component and 2.5 to the mandatory funded component. For the NDC system individual accounts were created. In 2000 the first fund choices were made. The contributors can change funds any time during the year.

There is a gradual transition to the new system, beginning with persons born in 1939 and ending with persons born 1953. Persons born in 1934 will receive $20 \%$ of their benefit from the new system and 80 from the old system. These proportion 
change by $5 \%$ per year for each younger age, and persons born in 1954 and later are completely within the new system (see Palmer, 2001).

There is not doubt about advantages of notional defined contribution system in comparison with the benefit defined system. But it is obvious that concrete parameters of the reform (especially the contribution rate, the share of first and second pillar, the life expectancy when determining the anuity, and others) cannot be taken from the Swedish model. They depend on the concrete situation and tasks of the reform of a country. Nevertheless, some lessons from the Swedish conception of the pension reform can be drawn:

- a gradual and a good prepared, instead of a fussy introduction of reforms will bring more success and will avoid making mistakes;

- the notional defined contribution scheme brings more fairness and transparency into the redistribution of sources. The low share of second pillar at the beginning of the reform seems to ensures more stable situation (compare the experience of Netherlands and Sweden);

- the introduction of some principles of the Swedish model in both Austrian and Czech reforms may be useful. There is, however, a substantial difference in the conception of the second pillar in Sweden and in prepared reforms in the Czech Republic and Austria, namely the mandatory part of the second pillar. Above we have already expressed our doubt about the difference between second and third voluntary pillars. Why the savers should voluntary save with another financial fund if they have the possibility to use the form of savings with state support in the framework of third pillar and housing savings? The present situation seems not to be fitting for further forms of voluntary savings and the role of the second pillar is substituted by the voluntary reinsurance, by the third pillar. Even if the state support would be reduced, these forms of savings are attractive, especially with the participation of employers. In fact we can speak identically with Holman (2002) about two pillar systems. The improvement and expansion of the voluntary reinsurance, the third pillar, will give the answer whether it is necessary and useful to introduce the mandatory second pillar. Our thesis expressed at the top of this study, namely to give the participants the possibility to chose among all existing forms of the private pension schemes, is therefore valid, but conditional, depending on the experience with successive introducing of new elements of pension reform. At the same time the improving conditions on the financial market play the important role. In the Czech Republic it is less developed than in Austria and therefore more risky for the participants.

Not last, and it may be the most important factor determining the success and prosperity of the reform, to have the well informed and consented participants of the pension system, with confidence in the success of the reform. This requires intensive educational work. At present, people have little knowledge about the preparation of the pension reform and are not yet convinced about its necessity. This is also one of causes of public demonstrations against measures of the PAYG system reforms.

\section{Conclusion}

Reforms of pension systems are very topical task. In conditions of population aging the public pension systems have only limited possibilities to sustain and develop high replacement ratio. Our study has aimed at explaining that the matter of pension reform is not limited to aging and fiscal problems. Only a portfolio of different kinds of pension benefits, and other kinds of savings together with a prolonged working age can ensure in the future a proper living standard and quality of life of the elderly. The aging of the population must be taken as a fact and as a challenge, 
taking into account that also the active part of one's lifetime is growing and the new elderly are becoming more educated and experienced. Not to exploit these resources would be a loss both for pensioners and the whole society.

All kinds of pension systems - both public and private - have their risks. Good operation of a system depends ultimately on the positive development of the economy in general and on the labour market in particular.

The higher economic level of a country is reflected, as a rule, in a higher replacement ratio as it is in our case when comparing the Austrian replacement ratio $80 \%$ of the net wage, with the Czech one $-57 \%$. On the other hand, a higher economic level and related generous public pension benefit cannot prevent difficulties in the pension system nor the discontent of people in conditions of population aging and threat of unemployment. Therefore, rich countries are also obliged to provide pension reforms and rethink the introduction of private pension schemes.

In the European context, especially at the beginning of the reform process, the public pension system (the first pillar) will retain a main role while reforms of this pillar continue. But besides further parametrical reforms, the intended transition from the defined benefit scheme to the notional defined contribution scheme in both compared countries would be the most marked change. Yet we must take into account that the advantages and disadvantages of different kinds of pension systems are not absolute; they penetrate one another and are to a certain degree mutual to all systems. Even in NDC system there must be a certain rate of redistribution and solidarity given, e.g. by the necessity of the existence of a minimum pension category, by the length of the fictitious qualifying period, and by the necessity of indexing the savings.

Both in Austria and the Czech Republic the supplementary private second and third pillars are declared to have a voluntary character. Concretely speaking, in Austria the second pillar has the form of occupational pension scheme, whereas in the Czech Republic it is hitherto only a theoretical slogan. In fact, there is not a substantial difference between the third pillar and second, funded pillar, defined as voluntary. Therefore, in this case we can speak only about two pillars system.

The poorer part of the population will hardly participate in the voluntary private pillar and there is a threat that excessive growth of income inequality may occur. And because the state cannot allow the impoverishment of a greater part of the population, a greater part of financial means should be provided from the public budgets in the form of social assistance - which means that we will again find ourselves in the situation of the growing role of the state budget in social affairs. Under these conditions it would be incongruous to give state support to savings of the richer part of the population.

The voluntary form of private pension scheme will hardly capture young generation, which confirms still small participation of young people in the third pillar and a great competition of housing savings with today's cheep loans. Therefore, the question for the future is either to keep a strong public pension scheme, or to introduce gradually a small share of mandatory payments to the private second pillar, which will grow incrementally as it is in the Swedish system. In this system of course there should be a legal guarantee in the form of obligatory reserves in the financial funds to prevent losses of the workers' money.

An opportunity should be given to the population to participate in different forms of pension insurance, both in occupational and financial pension funds. But it must be prepared conscientiously, based on experience with prior reform steps, first of all on experience with NDC system.

Pension reform is a process, and we must anticipate persistent changes in every kind of pension schemes. This is especially true for the voluntary character of 
private pension schemes because here the participants decide themselves how much to save. In every case, it is impossible to build up an ideal pension scheme once and forever.

Comprehensive work should be done to inform the future participants of the new pension schemes, because only a well-informed and consented population can ensure the appropriate realization of reform steps.

\section{References}

Baker, D., Kar, D. (2003), "World Bank Involvement in the Privatization of Public Pension Systems in Developing and Transition Countries." Background paper presented and the World Bank - Trade Union Meeting on Pension Reforms. Washington.

Baštýr̆, I. et al. (1995), "Report on Human Development Czech Republic" (in Czech). Prague, Research Institute of Labour and Social Affair.

Belabed, E. (2001), "The Role of Pension Funds in Economy and Society", in Etische Investments (in German). Wien: Gewerkschaft der Privatangestellten, pp. 59-66.

Bezděch, V. (2000), "Pension Systems in General and in Context with the Czech Republic (present situation and the need of reforms)" (in Czech). Prague, Czech National Bank, Research Work No. 25.

Bovenberg, A. L., van der Linden, A. S. M. (1997), "Can We Afford to Grow Old?" The Hague, CPB Netherlands Bureau for Economic Policy Analysis, Research Memorandum No. 134.

BSSG (2001), "Report on the Social Situation, Income, Social Insurance, Generations, Health (I., II)." Vienna, Bundesministerium für Soziale Sicherheit und Generationen.

CSO $(2000,2002)$, Statistical Yearbook of the CR (in Czech). Prague: Czech Statistical Office. (2001), "Czech Republic's Population Development in 2000" (in Czech). Prague, Czech Statistical Office.

EUROSTAT (2002), Yearbook. Luxembourg, Office for Official Publication of the European Communities.

Ewijk, C. van, De Ven, M. van (2003), "Pension Funds at Risk." Quarterly Review of CPB Netherlands' Bureau for Economic Policy Analysis, pp. 22-27.

Federal Ministry of Social Security, Generations and Consumer Protection (2003), "Social Protection Systems in Austria, A Survey." Vienna.

Gollier, J. J. (2002), "Pension Systems and Policy Issues: Private Pension System." Paris, Organization for Economic Cooperation and Development.

Guger, A., Mayrhuber, Ch. (2001), "Prospects of the Work Market and Pension Financing to 2030" (in German). WIFO Monatsberichte, (9), pp. 553-565.

Gruber, T., Höpfl, T. (2000), "The Social Dimension in the EU Enlargement Process" (in German). Economic and Political Journal, (1), pp. 15-40.

Handbook of the Austrian Social Security (in German) (2000). Wien, Hauptverband der Österreichischen Sozialversicherungstrager.

Holman, R. (2002), "Personal Accounts in the Healthcare and Pension Insurance" (in Czech). Prague, Center for Economics and Politics.

Holzmann, R. (1999), "The World Bank Approach to Pension Reform." Washington, World Bank, Discussion Paper No. 9807.

Kalliauer, H. (2001), "Pension Supplement instead of Redeem?" (in German). Wirtschafts- und Sozialpolitische Zeitschrift, 48, pp. 8-16.

Mayrhuber, Ch. (2002), "The Economy of the Social State - Point of Departure of the Financial Question" ( in German). Wirtschafts- und Sozialpolitische Zeitschrift, 49, pp. 105-122.

OECD $(1998,1999)$, "Austria, Economic Survey." Paris, Organization for Economic Cooperation and Development. (1999, 2000), “Czech Republic, Economic Survey.” Paris, OECD. (2001, 2002), "OECD in Figures". Paris, OECD.

Queisser, M., Vittas, M. (2000), "The Swiss Multi-pillar Pension System - Triumph of Common Sense?" Washington, World Bank, Policy Research Working Paper.

Palmer, E. (2001), "Financial Stability and Individual Benefits in the Swedish Pension Reform Model." Stockholm, National Social Insurance Board and Uppsala University. 
Pesando, J. E. (2002), "The Containment of Bankruptcy Risk in Private Pension Plans." Paris, OECD. RILSA (2002), "The Development of the Main Economic and Social Indicators" (in Czech). Prague, Research Institute of Labour and Social Affair, Working Paper No. 14, 15, 16.

Robinson, J. (2001), "Pensions - the Trade Union Perspective." Wirtschafts- und Sozialpolitische Zeitschrift, 48, pp. 38-48.

Stefanits, H., Part, P. (2001), "The Austrian Pension System." Vienna, Federal Ministry of Finance, Working Paper 7/2001.

Tálos, E., Wörister, K. (1998), Changes of the Social Security. Austria and the Neighbouring States. Vienna, Cologne, Weimar: Böhlau Verlag Ges. m.b. H.

Vavrejnová, M. (1996), "Public Expenditure and Social Welfare in the Czech Republic." Proceedings of the Workshop Welfare State in Transition: East and West. Berlin, Freie Universität.

Vavrejnová, M., Wörister, K. ( 2002), "Social Expenditures and their Sources (Czech - Austrian comparison)."Prague Economic Papers, 11(4), pp. 318-338.

WB (2000), "The Swiss Multi-pillar System." Washington, World Bank, Working Paper.

Wörister, K. (2001), "Social Security. Topical Development, Time Series" (in German). Wien, Kammer für Arbeiter und Angestellte. (1999), "Development of the Social Services in the Nineties" (in German). Wien, Kammer für Arbeiter und Angestellte.

Wörister, K. et al. (1998), "The Austrian Welfare State: A Survey of Social Security System" (in German). Vienna, Federal Ministry of Social Security, Generations and Consumer Protection.

www.mpsv. cz

www.cssz.cz

Compact Disk MPSV (2003) Pension Insurance Reform (in Czech) 